\title{
SOIL CHANGES IN WHITE PINE FORESTS OF NEW ENGLAND
}

\author{
By P. M. BARR
}

$\mathrm{C}$ ANADA'S forest problem of the present is undoubtedly protection, but just as certainly, the need of the future will be management. The orderly control of growing forests, which is the aim of management, must be based on a sound knowledge of silviculture, and the successful practise of that art depends in large measure upon an understanding of the relation between forest soils and timber'crops.

An excellent example of this fundamental relation is presented in Bulletin 16 of the Harvard Forest, "The Evolution of Soils as Affected by the Old Field White Pine-Mixed Hardwood Succession in Central New England," by B. G. Griffith, E. W. Hartwell, and T. E. Shaw. Griffith is a Canadian, the superintendent of the Aleza Lake Forest Experiment Station in British Columbia, and it is to be hoped that he may make contributions to Canadian silviculture that will be as practical, and yet have as basic a significance, as his work at Harvard forest.

The bulletin consists of a report, in detail, upon soil studies made in pine and hardwood forests of Massachusetts and New Hampshire, which were conducted by the three authors in 1928-29. A comprehensive introduction is given by Professor R. T. Fisher, the Director of Harvard Forest, and the results of the investigation are summarized, in conclusion, by Dr. P. R. Gast.

The make'up and appearance of the bulletin conform to the high standard set by previous publications of the Harvard Forest. The title is awkwardly long, for a bulletin with such logical and straight-forward contents. Surely it might have been distilled to a shorter name,-- easier to say and remember.

The investigation is a comparative study of the evolution of soil profiles under the old field white pine forests of central New England and the hardwood succession which commonly follows after logging in stands of this type. In his introduction, Professor Fisher describes the formation of humus soils in the region and traces the development of present stands of white pine or hardwoods which have become established on abandoned farm land. He sums up the chronology of the whole succession to which the study applies as an indeterminate past of mixed virgin forest, a hundred years of pasture and tillage, eighty years of pure white pine, and forty years of mixed hardwood.

The main portion of the bulletin opens with a brief discussion of the profiles of podsol and mull soils, which characterizes the softwood and hardwood forests of the central New England region, respectively.

In the field work, sixty-two plots were studied in each of the two forest types under consideration, on three soils, the Gloucester, Charlton and Brook- 
field series, as defined by the government soil surveys. The pine stands ranged in age from ten to eighty years, the hardwoods from five to forty years. In each forest type the study-areas included various conditions of aspect, moisture, and slope. The plots were circular, varying in size from $1 / 100$ to $1 / 4$ acre, depending on the size of the timber. Profile measurements, soil samples, and notes of physical conditions were taken from three holes dug about the centre of each plot.

Particular care was taken in the field to note the effect of forest succession on soil tilth, which is defined as the result of the combination of consistency, structure, and flocculation. The examinations of the various profiles indicated that soil tilth can be greatly changed within a single forest rotation. In a softwood stand with dense foliage the organic horizons, undergoing no decomposition, form a thick layer on the surface of the ground, keeping the temperature and moisture of the soil fairly uniform for comparatively long intervals, a condition which is unfavorable for breaking up its structure. Under a hardwood stand, with a thin organic layer, alternate freezing and thawing, wetting and drying, loosen and focculate the soil and bring it into good physical condition.

In addition to the main work on the old-field types, 105 soil profiles were examined in virgin hardwood and pine-hemlock forests, from 150 to 200 years of age, in Southern New Hampshire. These profiles were considered to be samples of conditions formerly obtaining in the climax forest on the areas where the present stands of second-growth pine and hardwoods were studied.

The most interesting part of the bulletin is the description of profile changes, which is admirably illustrated by a diagram, based on the field data, showing the evolution of profiles under old-field pine and the succeeding hardwoods. As the pine stand becomes established on the abandoned farm land, layers of humus, duff, and litter accumulate, reaching a thickness of over two inches in 60 years. During this period the dark brown upper layer of mineral soil, produced by decomposed organic admixtures from cultivation, diminishes, and at 40 years a leached layer begins to appear.

During the first ten years of the hardwood occupation the surface organic layers, accumulated under the pine, disappear. Most of the hardwood litter decomposes annually and the entire organic horizon is less than an inch thick. The dark brown layer of mineral soil deepens considerably, its rate of development varying with the species of hardwood in the stand. The leaves of ash, elm, basswood and birch decay rapidly, building up the dark brown horizon; oak, beech, and chestnut decay slowly, while hornbeam, aspen, cherry and maple are intermediate.

In the laboratory, the soil samples were examined in four series of analyses, as follows:- 
1. Determination of texture, by Bouyoucos' hydrometer method, for the purpose of classification into sands, loams, or clays, as defined by the U. S. Bureau of Soils, and also of finding the colloidal content.

2. Determination of organic matter, by ignition loss of the soil particles, in two series, under $1 \mathrm{~m} . \mathrm{m}$. and $5 \mathrm{~m} . \mathrm{m}$. in diameter, respectively.

3. Hydrogen-ion concentration and buffer content, by the quinhydrone method.

4. Nitrogen content, by the Kjeldahl method.

Similar analyses were made of the samples from both the old-field and the climax forest types.

In conclusion, the study is summarized as showing that, in respect to soil qualities, the effects of a pure pine type as contrasted with those of mixed hardwoods are comparable to the effects of poor farming and good farming. A farm soil is kept in the best possible condition for plant growth by crop rotation, by the addition of fertilizer, by ploughing under cover crops, by liming, and by tilling. In forest crops in the region under study, the good effects of these measures are provided by the natural development and maturity of hardwood stands. The influences at work under the cover of such a type are analagous to cultivation and tilling. The alkaline materials in the leaves may even take the place of liming.

Under a pine stand the decomposition of organic debris is arrested, fungal activity is checked and available nitrogen diminishes. In closing, Dr. Gast emphasizes, most pertinently, that sustained fertility is as indispensable to good forestry as it is to farming. Silviculture can accompany this, by establishing the species most favorable to soil development, and by extending their beneficial effects through timely and appropriate treatment.

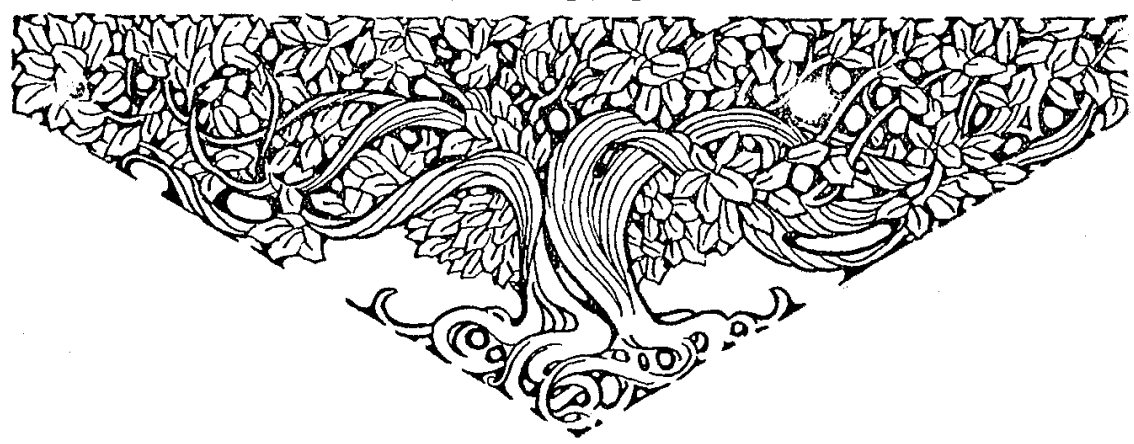

